\begin{tabular}{|l|l|l||}
\hline \multicolumn{2}{|c|}{ PublisherInfo } \\
\hline \hline PublisherName & $:$ & BioMed Central \\
\hline \hline PublisherLocation & $:$ & London \\
\hline \hline PublisherImprintName & $:$ & BioMed Central \\
\hline \hline
\end{tabular}

\title{
Archaeal snoRNAs
}

\begin{tabular}{|l|l|l||}
\hline \multicolumn{2}{|c|}{ ArticleInfo } \\
\hline \hline ArticleID & $:$ & 3627 \\
\hline \hline ArticleDOI & $:$ & $10.1186 /$ gb-2000-1-2-reports0050 \\
\hline \hline ArticleCitationID & $:$ & reports0050 \\
\hline \hline ArticleSequenceNumber & $:$ & 24 \\
\hline \hline ArticleCategory & $:$ & Paper report \\
\hline ArticleFirstPage & $:$ & 1 \\
\hline \hline ArticleLastPage & $:$ & 3 \\
\hline \hline & & RegistrationDate : 2000-5-3 \\
ArticleHistory & $:$ & Received \\
\hline ArticleCopyright & $:$ & BioMed Central Ltd2000-5-3 \\
\hline \hline ArticleGrants & $:$ & \\
\hline \hline
\end{tabular}




\begin{tabular}{|l|l|l||}
\hline ArticleContext & $:$ & 130591122 \\
\hline
\end{tabular}

Rachel Brem

\section{Abstract}

Small RNAs involved in rRNA methylation and ribosome biogenesis have been found in Archaea.

\section{Significance and context}

Eukaryotic ribosome formation occurs in a special compartment, the nucleolus, and uses small nucleolar RNAs (snoRNAs) in many assembly and modification steps. One class of snoRNAs, containing motifs called the $\mathrm{C}$ and $\mathrm{D}$ boxes, appears to hybridize to ribosomal RNA (rRNA) and tag it for ribose methylation at specific bases. Omer et al. have found homologs to C- and D-box snoRNAs in Archaea. These results have important evolutionary significance, suggesting that the common ancestor of Eukarya and Archaea, although it probably had no nucleolus, had mechanisms for methylating rRNA.

\section{Key results}

Omer et al. began by generating antibodies to homologs of eukaryotic nucleolar proteins (fibrillarin and NOP56/58) from the archaeon Sulfolobus acidocaldarius. Immunoprecipitation with these antibodies yielded 18 putative small RNAs (sRNAs) with C- and D-box motifs. Next the authors asked whether their new putative sRNAs aided rRNA methylation. They found 14 rRNA sites complementary to the new putative sRNAs, suggesting that these were possible methylation sites. To test for methylation, the authors used the primer-extension pause assay, which measures the stall of reverse transcriptase when it hits a methylated base in an RNA transcript. Of the 14 predicted sites in rRNA, six caused a stall in the assay. Finally, Omer et al. used a computational screen for homology to sRNAs in other Archaea besides S. acidocaldarius. They found dozens of candidates; and of 13 rRNA sites tested, nine caused stalls in the rRNA primer-extension assay. Examining all their sRNA candidates in Archaea, Omer et al. found several general features: first, only a few predicted rRNA methylation sites are common between archaeal genera; second, archaeal sRNAs are smaller than human and yeast C- and Dbox snoRNAs; third, the number of sRNAs in an archaeal microorganism seems to correlate with the optimal growth temperature of the organism.

\section{Reporter's comments}


Now that Omer et al. and others have determined the role of C- and D-box snoRNAs, further, more advanced questions about ribosomal biogenesis can be asked. What is the enzyme that methylates rRNA, for example, and how does it recognize these sRNA tags? Thanks to Omer et al., biochemists will now be able to harness data from Archaea as well as other organisms to investigate these questions.

\section{Table of links}

Science

\section{References}

1. Omer AD, Lowe TM, Russell AG, Ebhardt H, Eddy SR, Dennis PP: Homologs of small nucleolar RNAs in Archaea. Science. 2000, 288: 517-522. 0036-8075 